\title{
Genetic Evidence in Support of the Recognition of the Kaputar Rock Skink, one of New South Wales' Most Range-restricted Vertebrate Species
}

\author{
Ross A. Sadlier ${ }^{1,3} \mathbb{D}$, Greta J. Frankham ${ }^{1}$ (D) Cecilie A. Beatson $^{1}(\mathbb{D}$, \\ Mark D. B. Eldridge ${ }^{1}$ (iD) AND Jodi J. L. RoWley ${ }^{1,2}$ (iD \\ ${ }^{1}$ Australian Museum Research Institute, \\ Australian Museum, 1 William Street, Sydney NSW 2010, Australia \\ ${ }^{2}$ Centre for Ecosystem Science, School of Biological, Earth and Environmental Sciences, \\ University of New South Wales, Sydney NSW 2052, Australia \\ ${ }^{3}$ Outwest Reptile Consulting Services, \\ Montefiores Street, Wellington NSW 2820, Australia
}

\begin{abstract}
The existence of the Kaputar Rock Skink, a morphologically distinct Egernia population restricted to the Nandewar Ranges in northern New South Wales, has been known for decades. However, no comprehensive description or diagnosis of the taxon has been published in the scientific literature, and its distinctiveness largely assumed. As part of a study investigating the genetic differentiation of faunal populations on the Nandewar Range, comparisons between the Kaputar Rock Skink and east Australian Egernia striolata-group species were undertaken. The results indicate that the Kaputar Rock Skink is a distinct genetic lineage, showing species-level divergence from other Egernia species. Field studies suggest the Kaputar Rock Skink is restricted to an extremely narrow band of rock habitat above $1000 \mathrm{~m}$ or more in elevation, and only occupies retreat and sheltering sites near cliff edges or in areas of extensive outcropping rock. It now appears to be a cool-adapted species constrained to high elevation habitat by niche conservatism. Field studies suggest the availability of suitable habitat on the summit areas of the Nandewar Ranges is highly limited, making it vulnerable to several potentially threatening processes, including anthropogenic climate change. The name Contundo roomi was erected for the Kaputar Rock Skink by Wells \& Wellington in 1985, and we recommend Egernia roomi (Wells \& Wellington, 1985) as the name for the Kaputar Rock Skink.
\end{abstract}

\section{Introduction}

The Kaputar Rock Skink, a taxon restricted to the Nandewar Ranges at the eastern edge of the northwest plains of New South Wales (see Fig. 3), has been known for over 25 years, and has appeared as an unnamed species of Egernia in the Field Guide to Reptiles of New South Wales (Swan et al., 2014; 2017) for over a decade. However, no comprehensive morphological description or diagnosis for the species has been presented in the scientific literature. Independent information resulting from our recent field and genetic studies support recognition of the Kaputar Rock Skink as a distinct species, one with specific and highly-restricted habitat preferences, and is of particular conservation concern.

The Nandewar Range is the eroded remnant of a massive shield volcano, and rises out of the surrounding landscape

Keywords: Scinidae; Egernia roomi; Kaputar; Nandewar Range; Cytochrome b; montane; threatened; climate change

Taxonomic registration: (LSID publication) http://zoobank.org/297B60F9-4BDF-44A9-911D-40404FF939DC

Corresponding author: Ross A. Sadlier ross.sadlier@bigpond.com

Received: 28 August 2018 Accepted: 26 March 2019 Published: 28 August 2019 (in print and online simultaneously)

Publisher: The Australian Museum, Sydney, Australia (a statutory authority of, and principally funded by, the NSW State Government)

Citation: Sadlier, Ross A., Greta J. Frankham, Cecilie A. Beatson, Mark D. B. Eldridge, and Jodi J. L. Rowley. 2019. Genetic evidence in support of the recognition of the Kaputar Rock Skink, one of New South Wales' most range-restricted vertebrate species. Records of the Australian Museum 71(5): 183-197. https://doi.org/10.3853/j.2201-4349.71.2019.1716

Copyright: @ 2019 Sadlier, Frankham, Beatson, Eldridge, Rowley. This is an open access article licensed under a Creative Commons Attribution 4.0 International License (CC BY 4.0), which permits unrestricted use, distribution, and reproduction in any medium, provided the original authors and source are credited. 



Figure 1. The peaks of the Nandewar Range from a distance $(A)$ and at its base $(B)$ as it rises from the surrounding plains.

to altitudes over $1000 \mathrm{~m}$ (Fig. 1). The Australian Museum Research Institute recently undertook field studies to investigate if the Nandewar Range has served as a mesic refuge for reptiles, amphibians and mammals, particularly for taxa shared with the adjacent northern tablelands of the Great Dividing Range. One of the targets for investigation was the Kaputar Rock Skink (Fig. 2), assumed to be allied to the 'striolata-group' within Egernia.

In morphology, the Kaputar Rock Skink is similar in overall appearance to the east Australian members of the Egernia striolata-group. This group includes the Tree Skink Egernia striolata, the Eastern Crevice Skink Egernia mcpheei and the Black Rock Skink Egernia saxatilis, the latter comprising two recognized subspecies (saxatilis saxatilis and saxatilis intermedia). All are of moderate size (average body length c. $100 \mathrm{~mm}$ ), have a depressed (ovoid) body form, and all (except the Kaputar Rock Skink) have a textured scale surface that is typically grooved or keeled (Swan et al., 2017). Egernia striolata, E. mcpheei and E. saxatilis intermedia are parapatric in distribution across eastern Australia (Fig. 3). Egernia striolata occurs over much of the inland areas of southern and central Queensland, the northern ranges and western division of New South Wales, and into South Australia (Cogger, 2014). By contrast E. mcpheei and E. s. intermedia have distributions that are much more limited. Egernia mcpheei occurs along the north coast of New South Wales, from the Hunter Valley to the Border Ranges region, inland to the eastern edge of the ranges of the northern tablelands (Swan et al., 2017), and E. saxatilis intermedia occurs on the central and southern 

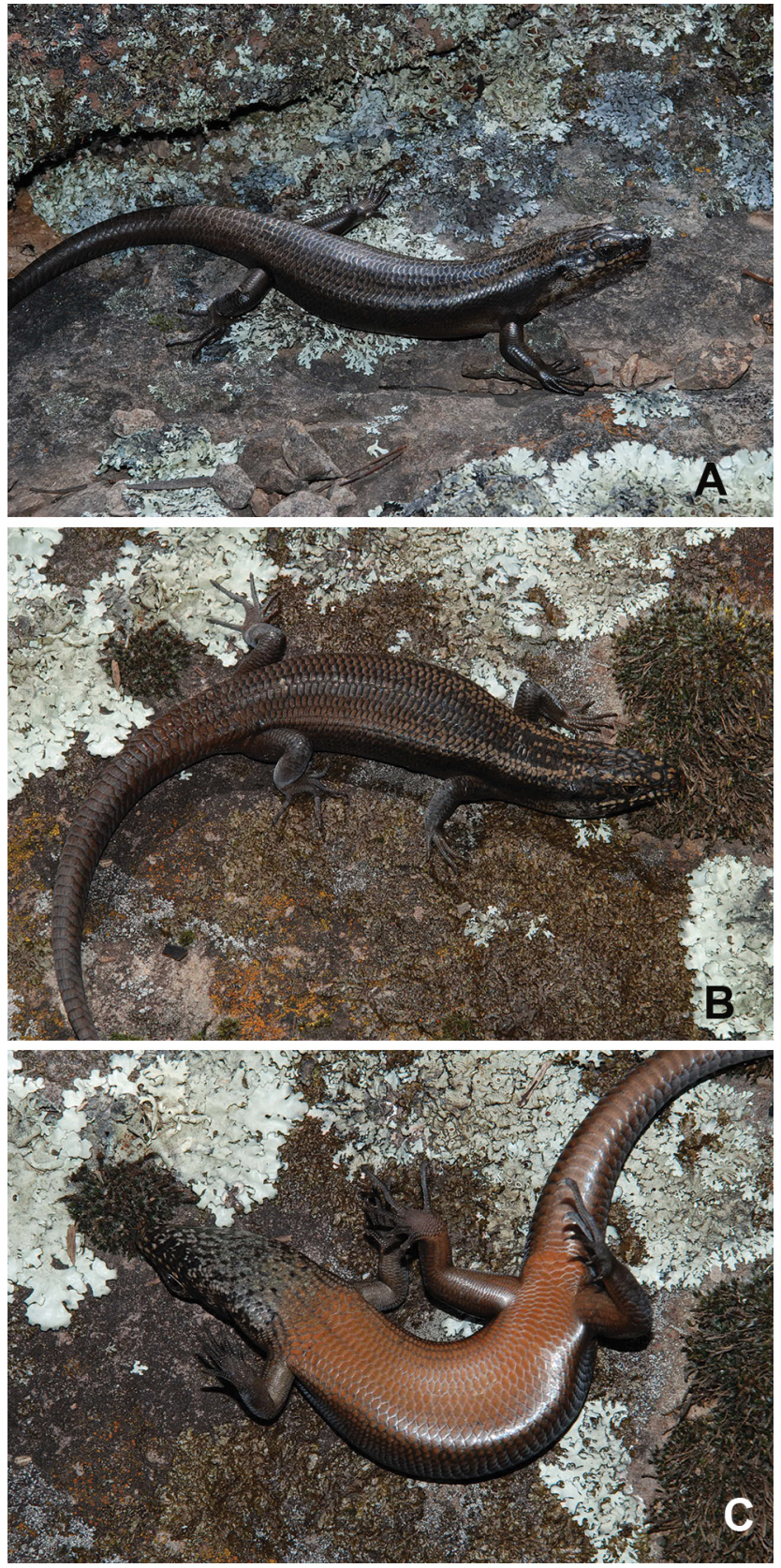

Figure 2. The Kaputar Rock Skink Egernia roomi showing the dark dorsal body colouration $(A, B)$ typical of the species, and extensive dull uniform orange colouration to the ventral surface $(C)$ that includes the chest, abdomen and underside of the tail.

tablelands and adjacent areas of the southwest slopes and south coast of New South Wales (Swan et al., 2017), and the ranges of Victoria west to the Grampians (Wilson \& Swan, 2017). The nominate subspecies E. s. saxatilis is restricted to the Warrumbungle Ranges on the northwest slopes of New South Wales. Here it sits isolated and 'surrounded' by E. striolata, a scenario not dissimilar to that of the Kaputar Rock Skink. The differences in morphology between the named east Australian striolata-group species are subtle (Swan et al., 2017) but their recognition as distinct biological entities has not been questioned, nor has their distinctiveness from the western members of the group that occur primarily in Western Australia (Gardner et al., 2008). As part of our study investigating the extent of genetic differentiation of fauna populations on the Nandewar Range, we undertook comparisons between the Kaputar Rock Skink and east Australian striolata-group species.

To assess the extent of historical connectivity of montane and rocky habitats between the Nandewar and Great Dividing Ranges we also investigated the extent of genetic divergence between populations of two habitat specialists which are distributed on the northern tablelands but extend west to the Nandewar Range, the Tussock Skink Pseudemoia pagenstecheri and the Granite Belt Thick-tailed Gecko Uvidicolus sphyrurus. Pseudemoia pagenstecheri is a species primarily associated with high elevation woodland habitat with tussock grass groundcover, and has a distribution that extends along the Great Dividing Range in New South Wales and Victoria. Across its range $P$. pagenstecheri occurs as several disjunct regional populations: one in the southern montane environments, one in high elevation forest habitat of the central ranges of New South Wales, and one in high elevation forest habitat of the northern tablelands of New South Wales, with the population on the Nandewar Range an isolated outlier. Uvidicolus sphyrurus is primarily a rockdwelling species with a distribution that encompasses the northern tablelands of New South Wales and areas of the adjacent north-west slopes. The population on the Nandewar Ranges lies at the western limits of the species' distribution. It occupies habitat across a broad altitudinal range, indicating a correspondingly broad thermal tolerance, but is highly dependent upon the presence of suitable rock habitat.

\section{Methods and materials}

Distribution: The distribution of the Kaputar Rock Skink was assessed from records in the Australian Museum specimen database and from survey work carried out over two days in September 2015 at Kaputar National Park (hereafter KNP). Searches for the Kaputar Rock Skink focused on high elevation rocky habitat, and included sites between 1350 and $1480 \mathrm{~m}$ in elevation. The species' potential Area of Occupancy (the area contained within the shortest continuous imaginary boundary which can be drawn to encompass all the known, inferred or projected sites of occurrence of a taxon-hereafter AOO) and Extent of Occurrence (the area within its 'extent of occurrence' which is occupied by a taxon-hereafter EOO) as defined under IUCN Red List criteria (2012) were estimated from areas above $1000 \mathrm{~m}$ and $1200 \mathrm{~m}$ elevation calculated on a range map created in ArcMap 10.2.2 using the WorldClim Altitude raster (Hijmans et al., 2005). The AOO was measured using the Calculate Geometry tool in ArcMap, and EOO was measured using the IUCN EOO Calculator tool v1.2. In addition, reference was made to the Australian Museum specimen database to determine the geographically nearest records of E. striolata for evidence of regional sympatry between the two taxa.

Morphology: Information for morphological comparisons between the Kaputar Rock Skink and east Australian striolata-group species E. striolata, E. mcpheei, E. saxatilis saxatilis and E. saxatilis intermedia was limited to published information (primarily Swan et al., 2017; Wilson, 2015) for size, body shape, scalation characteristics and colouration, supplemented by personal observations made during the 2015 field survey, as priority over the redescription of the morphology of the species is a work in 


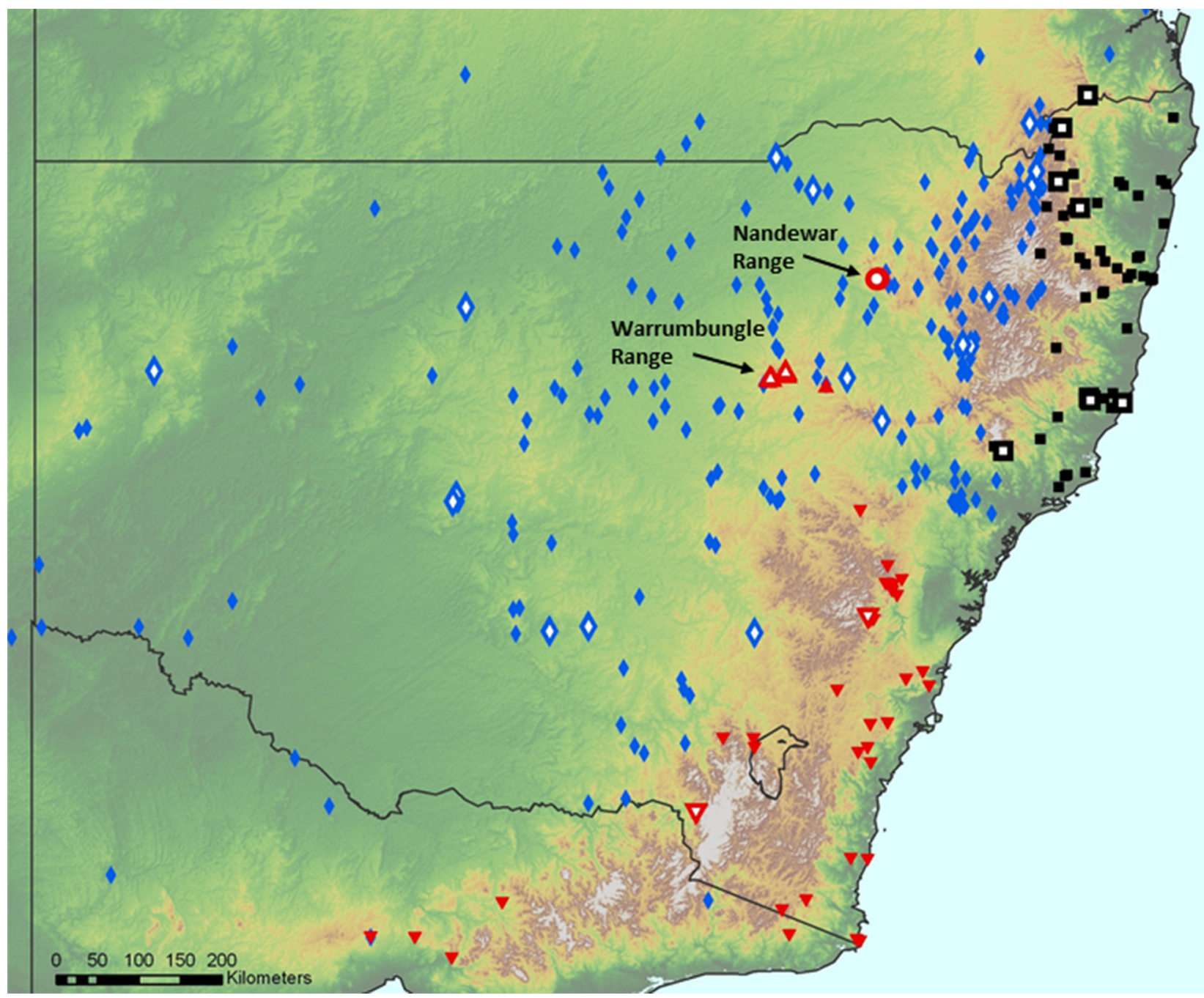

Figure 3. Elevation image of New South Wales showing the distribution of the east Australian striolata-group species in the state based on specimen records in the Australian Museum (closed symbols) and those samples analysed in the genetic study (open symbols): Egernia striolata (blue diamond), Egernia saxatilis saxatilis (red triangle); Egernia saxatilis intermedia (red triangle upside-down); Egernia mcpheei (black square) and the Kaputar Rock Skink Egernia roomi (circle in red).

progress by Dr Glenn Shea, Sydney University.

Genetics: Sampling for genetic comparisons included tissue samples held in the Australian Museum Herpetology Tissue Collection (Appendix 1) of the Kaputar Rock Skink $(n=5)$ and representatives of the described east Australian striolatagroup species E. striolata, E. mcpheei, E. saxatilis saxatilis and $E$. saxatilis intermedia $(\mathrm{n}=42)$. Our sampling for the east Australian striolata-group taxa was comprehensive, including representatives from across the geographic range of each species (see Fig. 3). For the widespread species $E$. striolata, 23 samples representing 15 independent locations from across New South Wales were utilized. Four taxa were used as progressive outgroups. Near outgroup taxa included Egernia formosa, a representative of the western striolata-group species and Cunningham's Skink Egernia cunninghami as a representative from the genus Egernia not generally considered as a member of the striolata-group. More distantly related outgroup taxa included: the Desert Skink Liopholis inornata as a representative of a group of species formerly within Egernia but now recognized as a distinct genus (Gardner et al., 2007), and the Eastern Bluetongue Skink Tiliqua scincoides as a representative member of a significantly broader evolutionary group to which the species of Egernia also belong (= the Egernia group sensu Greer, 1979, later as the Egernia subgroup of the Mabuya group sensu Honda et al., 2000).

Sampling for P. pagenstecheri and U. sphyrurus, the two additional species of lizards chosen for the supplemental study, was from tissue samples held in the Australian Museum Herpetology Tissue Collection (Appendix 2). For $P$. pagenstecheri this included samples from the Nandewar Range ( $n=2)$, two locations on the northern tablelands ( $\mathrm{n}=$ 4), Coolah Tops, an outlier of the Dividing Range at the head of the Hunter River valley $(\mathrm{n}=1)$, and two locations on the southern tablelands $(\mathrm{n}=3)$. Sampling for $U$. sphyrurus was modest as only a few samples were available, and included single individuals from Mt Yulladunida on the Nandewar Range, from near Copeton Dam on the western slopes of the northern tablelands, and from Moonbi at the southern end of the northern tablelands.

DNA was extracted from frozen tissues using the ISOLATE II Genomic DNA Kit (Bioline, Australia) under standard conditions and a partial region of the mitochondrial Cytochrome b (Cyt b) gene was amplified using the L14841 
and H15149 primers (Kocher et al., 1989). Cyt b was chosen over more commonly examined mitochondrial DNA (mtDNA) regions in reptiles (e.g., ND2, ND4) as it produced consistent amplification across all examined specimens including outgroups, which could not be achieved using other mtDNA primers. Polymerase Chain Reactions (PCRs) were carried out in $25 \mu \mathrm{l}$ reactions using 100-500 ng of genomic DNA, 1 x Reaction Buffer (Bioline MyTaq Red Reagent Buffer; Bioline, Australia), 2 pmol of each primer and 0.5U Bioline MyTaq Red DNA polymerase. Negative controls were included in each PCR. PCRs were carried out under the following cycling conditions; Initial $94^{\circ} \mathrm{C}$ ( $\left.3 \mathrm{~min}\right)$ denature, followed by 38 cycles of $94^{\circ} \mathrm{C}(20 \mathrm{sec})$ denature; $55^{\circ} \mathrm{C}(40 \mathrm{sec})$ annealing; $72^{\circ} \mathrm{C}(40 \mathrm{sec})$ extension, followed by a final $72^{\circ} \mathrm{C}$ extension step. Amplified PCR products were cleaned using ExoSap-ITC) (USB Corporation, Cleveland, Ohio, USA) and sequencing was resolved on an AB 3730xl Sequencer at the Australian Genome Research Facility, Australian Museum, Sydney. Sequences were checked and edited with reference to chromatograms using Sequencher v 5.3.2 (Gene Codes Corporation, Ann Arbor, MI, USA) and lodged with GenBank. Sequences were aligned using the Clustal X algorithm implemented in MEGA 7 (Tamura et al., 2013).

Phylogenetic relationships among haplotypes were estimated using maximum likelihood (ML) and Bayesian inference (BI). An appropriate model of evolution (HKY + Г) was determined using MEGA v 6 (Nei \& Kumar, 2000; Tamura et al., 2013), based on the Bayesian Information Criterion (BIC scores) and Akaike information criterion, corrected (AICc scores) and all phylogenetic analyses were carried out using this model.

Maximum Likelihood (MI) was estimated using MEGA v 6 (Tamura et al., 2013) with 500 bootstrap replicates. Bayesian Inference (BI) analysis was conducted in MrBayes 3.2 (Ronquist et al., 2012). Metropolis-Coupled Markov Chain Monte Carlo sampling was used to calculate posterior probability. The analyses were run using default settings for priors. Two independent analyses ran simultaneously with four chains per run ( 1 cold, 3 hot). The chains were run for 1 million generations and sampled every 100 generations to obtain 10,000 sampled trees. Tracer 1.6 (Rambaut et al., 2014) was used to check for chain convergence and adequate Effective Sample Size ( $>200)$. Bootstrap values (percentages) and posterior probabilities (decimals) were used to assess the level of branch support. Values over $80 \%$ and 0.90 were considered well supported branches (Fig. 5).

\section{Results}

Distribution: Based on specimen records in the Australian Museum, the Kaputar Rock Skink has only been rarely recorded prior to our study. The earliest records are a single specimen from 'Mt Kaputar' collected by W. McReaddie in December 1965, and two others from 'Mt Kaputar top' collected by P. Room in December 1975-no further data accompanies these specimens. A collection of eight specimens was made by the senior author in October 1980, one from Mt Kaputar (c. 1480 m), the remainder from the northwest side of Mt Dowe (c. 1420-1440 m). A further two specimens were collected on the Mt Kaputar summit by G. Swan and D. O'Mealy in 1998 from rockpiles. Field work undertaken in September 2015 detected the Kaputar Rock Skink at two sites, Mt Dowe (the same site investigated in 1980) and The Governor (c. 1370 m). As such, the species has been detected from three separate locations with certainty c. $2 \mathrm{~km}$ (Mt Dowe to Mt Kaputar) to $3 \mathrm{~km}$ straight line distance apart (Mt Dowe and Mt Kaputar to The Governor), and covering a range of altitudes between 1370 and $1480 \mathrm{~m}$.

Evidence of regional parapatry between Egernia striolata and the Kaputar Rock Skink was identified based on records in the Australian Museum specimen collection. Egernia striolata was found to occur at six areas within a $50 \mathrm{~km}$ radius of Mt Kaputar, including Narrabri (c. $35 \mathrm{~km} \mathrm{SW-}$ AMS R.1050, R.1054-55), Bellata (c. 50 km NW-AMS R.94783), Terry Hie Hie area (c. 40 km N-AMS R.112852), Horton River southwest of Bingara (c. $30 \mathrm{~km} \mathrm{NE-AMS}$ R.92470, R.92473), Barraba area (c. $50 \mathrm{~km} \mathrm{E-AMS}$ R.2896-98, R.41828) and Boggabri (c. $50 \mathrm{~km} \mathrm{S-AMS}$ R.2005, R.4171).

Morphology: Reference to the descriptions of the Kaputar Rock Skink, E. saxatilis, E. mcpheei and E. striolata in Swan et al. (2017) and Wilson (2015) identified differences between these taxa relating to average and maximum body size, texture of the dorsal scales, and colouration. Features of dorsal scalation unequivocally differentiate the Kaputar Rock Skink from E. saxatilis, the texture of the scales of the Kaputar Rock Skink being smooth or slightly grooved $v s$ the scales having ridges low in profile but peaked and sharp at the posterior end of the scale. Aspects of colouration also serve to distinguish the two species. Both are dark in colouration overall, but the Kaputar Rock Skink has a paler dorsolateral area anteriorly whereas the dorsal colouration of $E$. saxatilis is relatively uniform in pattern - both are similar in ventral colour. Distinguishing the Kaputar Rock Skink from $E$. mcpheei and E. striolata is less straightforward from the morphological information published. The Kaputar Rock Skink is smaller in average (105 vs $120 \mathrm{~mm}$ ) and maximum (121 vs $143 \mathrm{~mm}$ ) adult body size than E. mcpheei, the texture of the scales is smooth or with low and gently rounded ridges
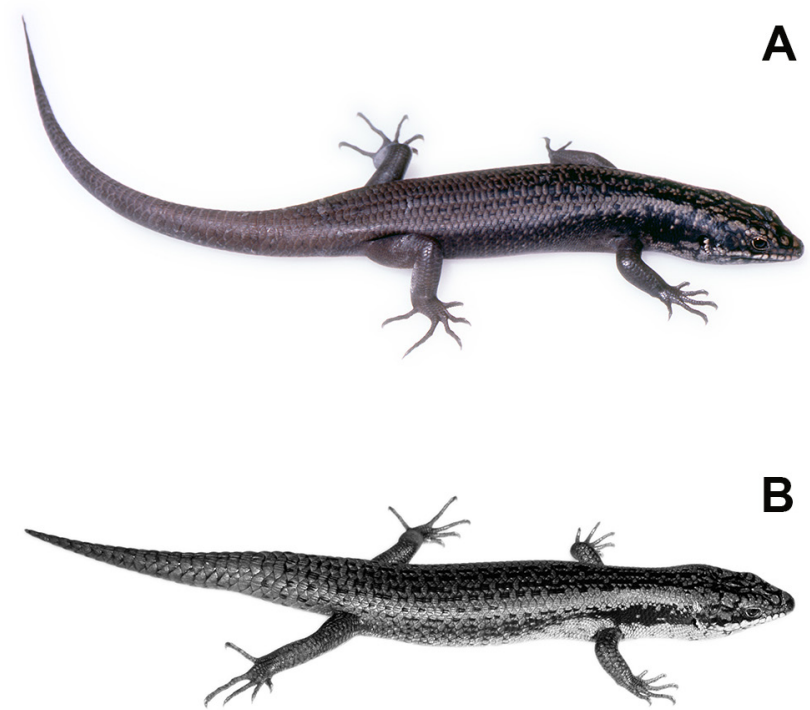

Figure 4. Comparison of dorsal colour pattern between typical individuals of Egernia roomi from Mt Dowe (AMS R.97913) and a regionally parapatric Egernia striolata from Terry Hie-Hie 40 $\mathrm{km}$ north (AMS R.112852). 


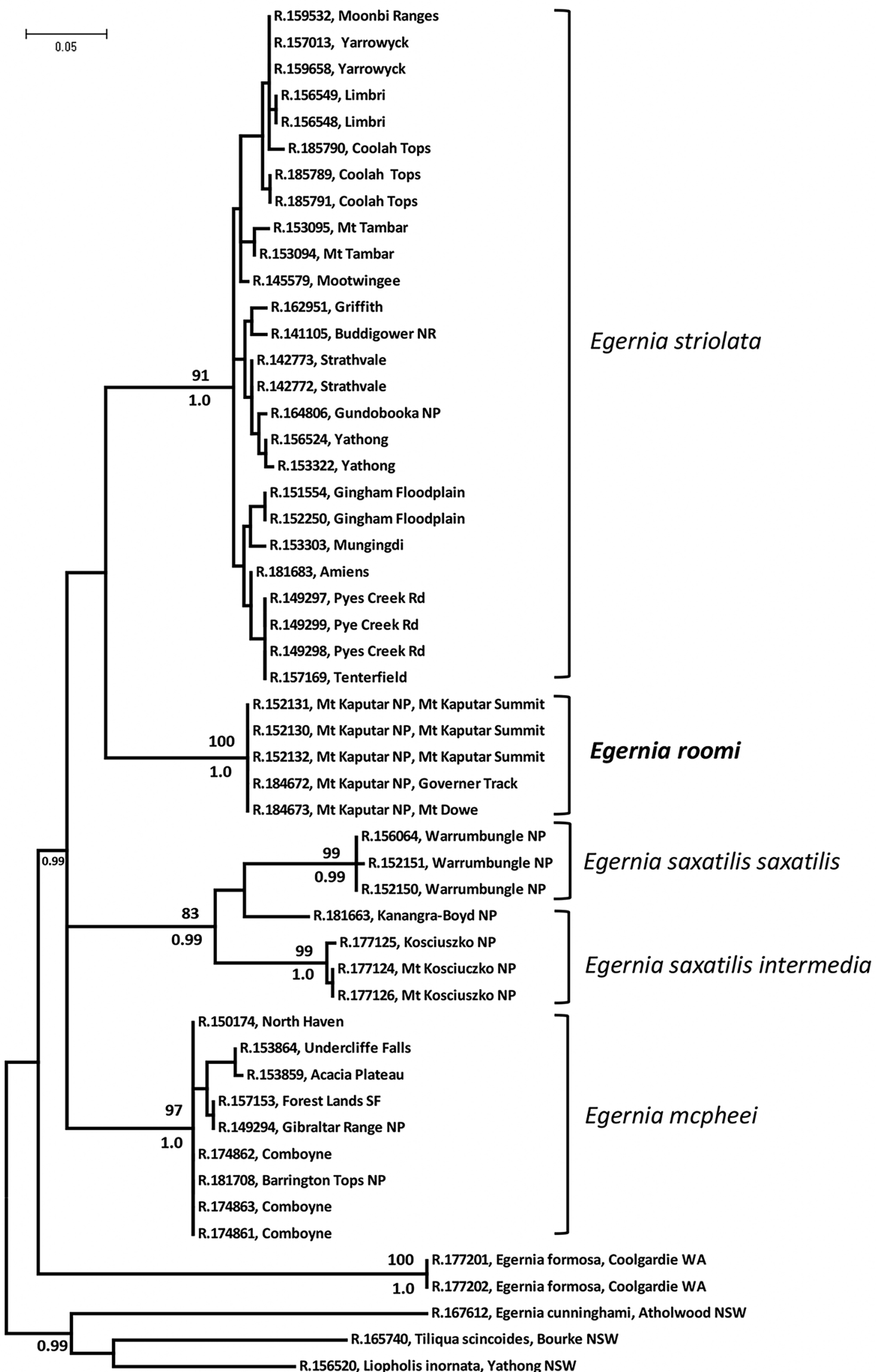

Figure 5. Phylogeny based on Maximum Likelihood estimates of the east Australian striolata-group species and selected outgroup taxa inferred from partial Cytochrome b sequence. Both Maximum Likelihood and Bayesian Inferenced resolved similar topography. Bootstrap values (percentages) are present above the node and posterior probabilities (decimals) are presented below the node, only values over $70 \%$ or 0.7 are shown. 
$v s$ having ridges low in profile with a blunt posterior end, and there are subtle differences in colouration of the dorsal surface (broad paler dorsolateral area anteriorly vs overall dark colouration above) and ventral surface (dull but deep orange $v s$ orange to orange-yellow). Differences between the Kaputar Rock Skink and E. striolata for average (105 vs $95 \mathrm{~mm}$ ) and maximum (121 vs $119 \mathrm{~mm}$ ) adult body size are subtle, as are differences in the texture of the surface of the dorsal scales of the body (smooth to slightly grooved vs grooved). However, the two taxa differ markedly in colouration, particularly in the extent of dark markings to the scales of the dorsal surface of the body, in the uniformity and intensity of orange colouration on the ventral surface of the chest, abdomen and underside of the tail, and in the intensity of the blueish-grey throat colour. The dark markings to the dorsal surface of a typical individual of the Kaputar Rock Skink are restricted to the anterior part of the body and tend to coalesce, whereas those of regionally parapatric E. striolata are well-defined and continue down the entire length of the body (Fig. 4).

Genetics: DNA sequences were obtained for 278-307 bp of Cyt b gene. Both Maximum Likelihood and Bayesian Inference methods resolved phylogenetic trees with similar topography illustrating that, even with this short $C y t b$ fragment, the east Australian striolata-group species striolata, mcpheei, and saxatilis are distinct and wellsupported independent genetic lineages (Fig. 5). A deep level of genetic differentiation between these taxa was evident in pairwise comparisons (Table 1). The Western Australian striolata-group representative formosa was also resolved as a highly-supported and distinct independent genetic lineage. Phylogenetic analyses also resolved all individuals of the Kaputar Rock Skink as a genetic group distinct from all other recognized taxa included in the study. The five individuals sampled came from three locations over two distinct time points (1998 and 2015), and all had the same $C y t b$ haplotype. Although the analysis retrieved E. striolata as the sister to the Kaputar Rock Skink, support for this arrangement was low (Fig. 5), highlighting the Kaputar Rock Skink's distinctiveness from E. striolata. No evidence of genetic introgression was detected between the individuals representing the Kaputar Rock Skink population and any of the east Australian striolata-group species. This is a particularly significant result with respect to $E$. striolata. This species was sampled extensively throughout its range in New South Wales and included populations in moderately close geographical proximity to the Kaputar Rock Skink, as represented by individuals from the Tambar Ranges (c. $120 \mathrm{~km}$ south), the Gingham floodplain (c. $150 \mathrm{~km}$ north), and Yarrowyck (c. $120 \mathrm{~km}$ east on the northern tablelands). Pairwise comparisons between the Kaputar Rock Skink and the east Australian striolata-group species (Tables 1 and 2) showed a high level of genetic differentiation for the $C y t b$ gene with E. striolata (12.4-15.6\%), E. saxatilis saxatilis (15.5-16.1\%) and E. saxatilis intermedia (16.5-18.2\%), E. mcpheei (12.9-15.9\%), and an even higher level when compared to the western striolata-group species $E$. formosa (24.4\%) and to E. cunninghami (22.8\%). Comparative levels of genetic differentiation between well-established scincid taxa for the $C y t b$ gene are seen in studies on the Australian scincid genus Saproscincus (Sadlier et al., 2005). This study gave average pairwise genetic distances of $11.1-14.3 \%$ between the species $S$. challengeri and $S$. spectabilis and 
Table 2. Matrix of genetic distances (range, with mean parenthetically) as percentage difference between populations of the east Australian species Egernia saxatilis.

\begin{tabular}{llccc}
\hline & & $\begin{array}{c}\text { E. s. saxatilis } \\
\text { Warrumbungle Ranges } \\
\mathrm{n}=3\end{array}$ & $\begin{array}{c}\text { E. } \text { s. intermedia } \\
\text { central tablelands } \\
\mathrm{n}=1\end{array}$ & $\begin{array}{c}\text { E. } \text { s. intermedia } \\
\text { southern tablelands } \\
\mathrm{n}=3\end{array}$ \\
\hline Egernia saxatilis saxatilis & Warrumbungle Ranges & $0.0-1.0(0.7)$ & - & \\
Egernia saxatilis intermedia & central tablelands & $9.1-9.9(9.4)$ & $0.0-0.7(0.4)$ & - \\
Egernia saxatilis intermedia & southern tablelands & $14.3-14.4(14.3)$ & 11.6 & 0.0 \\
\hline
\end{tabular}

16.5-23.7 between S. challengeri and S. rosei, considered to be 'relatively deep divergences'. Support for this extent of DNA sequence divergence representing species-level differences comes from an earlier study investigating speciation in Saproscincus utilizing allozyme electrophoresis (Sadlier et al., 1993) which independently established the species $S$. challengeri and $S$. spectabilis and $S$. rosei as distinct evolutionary entities.

Relationships amongst the genetic groups representing recognized taxa within the genus Egernia were not well resolved, and the values at primary and most secondary nodes within the genus were at best moderate. This was also a feature of an earlier study by Gardner et al. (2008) which more broadly sampled taxa across the traditional concept of 'Egernia' using several genes, and which at that time contained an extensive suite of species.

The comparison of populations of the Tussock Skink P. pagenstecheri in the supplemental study showed a low level of differentiation in pairwise comparisons between the Nandewar Range and Coolah Tops samples (3.3\%), and with the Riamukka sample from the south of the northern tablelands (4.2\%). However, there was markedly higher levels of differentiation with those from Stewarts Brook in the Mt Royal Ranges (12.5-13.0\%). Despite being geographically closer to the Nandewar Range, Coolah Tops and Riamukka populations, the population from Stewarts Brook on the Mt Royal Range is genetically more similar to populations from further south. This assessment of variation between populations of $P$. pagenstecheri across its range is limited by the absence of populations from the central tablelands region. However, it is sufficient to indicate the break in connectivity between the Nandewar Range population and proximal populations on the Great Dividing Range (Coolah Tops and Riamukka) is historically recent, and consistent with the breaks for other lizard taxa identified by Colgan et al. (2009) attributable to Pleistocene events. The comparison of samples of the Granite Belt Thick-tailed Gecko U. sphyrurus was limited in both the geographic coverage and number of samples available (one per location). It revealed a low level of differentiation (1.6\%) between individuals from the Nandewar Range and Copeton Dam (110 km NE) and slightly more elevated level of differentiation to Moonbi near Tamworth (3.7\%), similar to that between Moonbi and Copeton Dam individuals (4.1\%).

\section{Discussion}

Recognition of Egernia roomi for the Kaputar Rock Skink: The available genetic and morphological data supports recognition of the Kaputar Rock Skink as a distinct species. The taxonomic implications regarding the formal name applicable to the species rest with the legitimacy of the description of the species Contundo roomi as proposed by Wells \& Wellington (1985) under the requirements of the International Code of Zoological Nomenclature. This name was applied by Wells \& Wellington in 1985 to one of two specimens (AMS R.69587) from the summit of Mt Kaputar collected by Peter Room in 1975 . While clearly relating to the Kaputar Rock Skink this name has not been applied to this taxon in either the general or scientific literature.

The works by Wells \& Wellington $(1984,1985)$ were the subject of a case presented to the International Commission for Zoological Nomenclature for suppression for nomenclatural purposes by the Australian Society of Herpetologists (1987). In a separate submission Shea (1987) independently assessed the validity of actions contained in these works, and with regard to the description of Contundo roomi found that while the diagnosis presented was unworkable, it did not prevent the availability of this name under the code. The ICZN (1991) considered these works by Wells \& Wellington to represent a "clear rejection of virtually every tenet of the voluntary code of ethics", but ruled that the legitimacy of the taxa proposed be determined on a case by case basis against the rules of the ICZN. In a consideration of the type specimens of reptiles described by Wells \& Wellington $(1984,1985)$ residing in the Australian Museum collection Contundo roomi was regarded as "innominate" by Shea \& Sadlier (1999) in the absence of a workable diagnosis, and was listed as "Egernia sp. nov." pending "completion of studies on the Egernia striolata complex by G. Shea". No comment was given as to why this action was taken in precedence over the earlier statement by Shea (1987) regarding the availability of the name. The only other mention of the name roomi is by Cogger (2014) under the account of subspecies of Egernia saxatilis, but only in that its status was uncertain.

Our consideration of the availability of the name Contundo roomi is that the description of the species by Wells \& Wellington (1984) contains a diagnosis in words that purports to distinguish it from specific related taxa, even 
if erroneous. As such, we consider it meets the minimum requirements for recognition as a valid description at the time it was published, and as a consequence the name Contundo roomi has priority of application to the Kaputar Rock Skink. There is no independent data to support the recognition of the genus Contundo as proposed by Wells \& Wellington for this species and several other striolata-group species, and so the name used for the Kaputar Rock Skink is Egernia roomi (Wells \& Wellington, 1985). The formal redescription of the Kaputar Rock Skink is part of the ongoing work in progress by Shea on the striolata-group mentioned above.

Habitat of the Kaputar Rock Skink: The Nandewar Range is the remnant of the Nandewar Volcano, formed when a series of volcanic eruptions moved across the region 21 and 17 million years ago as the continent drifted slowly northward across a 'hotspot' in the Earth's mantle. The Nandewar Volcano was a shield volcano with gently sloping sides rising to a height of over $2100 \mathrm{~m}$ and was $50 \mathrm{~km}$ wide. The flows from its vents were extensive, with a north-south extent of about $160 \mathrm{~km}$, and east-west of about $100 \mathrm{~km}$. The next point of crustal weakness to pass above the same hotspot was the Warrumbungle area, where lava extruded from the Warrumbungle Volcano between 17 and 13 million years ago (Brovey Mapping Services).

Subsequently millions of years of erosion have created a landscape of lava terraces, volcanic plugs and ring dykes which are major landscape features of the Nandewar Range today. The highest point is Mt Kaputar at $1510 \mathrm{~m}$ in elevation, with twelve other peaks of at least $1200 \mathrm{~m}$, by contrast the surrounding plains lie at $230 \mathrm{~m}$ (Cartoscope). The Kaputar Plateau and Mt Dowe (both areas from which the Kaputar Rock Skink has been recorded), and Lindsay Rock Tops are ancient trachyte lava terraces, while The Governor (another record site from our survey) is a flat-topped flow remnant carved by erosion.

The Nandewar Range is linked by a narrow corridor of low ranges to the northern tablelands of the Great Dividing Range. The vegetation exhibits both western slopes and tablelands affinities, with the northern tablelands component representing an outlier surrounded by semi-arid plant communities. Areas over $1200 \mathrm{~m}$ are above the winter snowline, and at these higher elevations distinct sub-alpine vegetation communities have been identified, including open forests of mountain gum and snow gum with snow grass groundcover on higher elevation slopes and flats, and heathland and open herbfields in exposed areas with thin soils (DEC, 2006).

All records of the Kaputar Rock Skink have been from areas of outcropping rock (Fig. 6) that are part of remnant lava terraces of the Kaputar plateau area between 1360 and $1480 \mathrm{~m}$ elevation. All sites have been in close proximity to the periphery or rim of the plateau, not from outcropping rock within woodland of the interior of the plateau. On rock surfaces where it has been observed the species appears to only occupy sheltering sites of rock overlying rock, not rock on soil. This is in keeping with the habits of other members of the striolata-group which occupy naturally-existing shelter sites such as rock crevices or, in the case of E. striolata and E. mcpheei, also the use of tree hollows and gaps in dead and fallen timber. Reference to satellite imagery indicates the majority of escarpment rock habitat lies above $1100 \mathrm{~m}$. Assuming the extent of this high elevation rock habitat to be
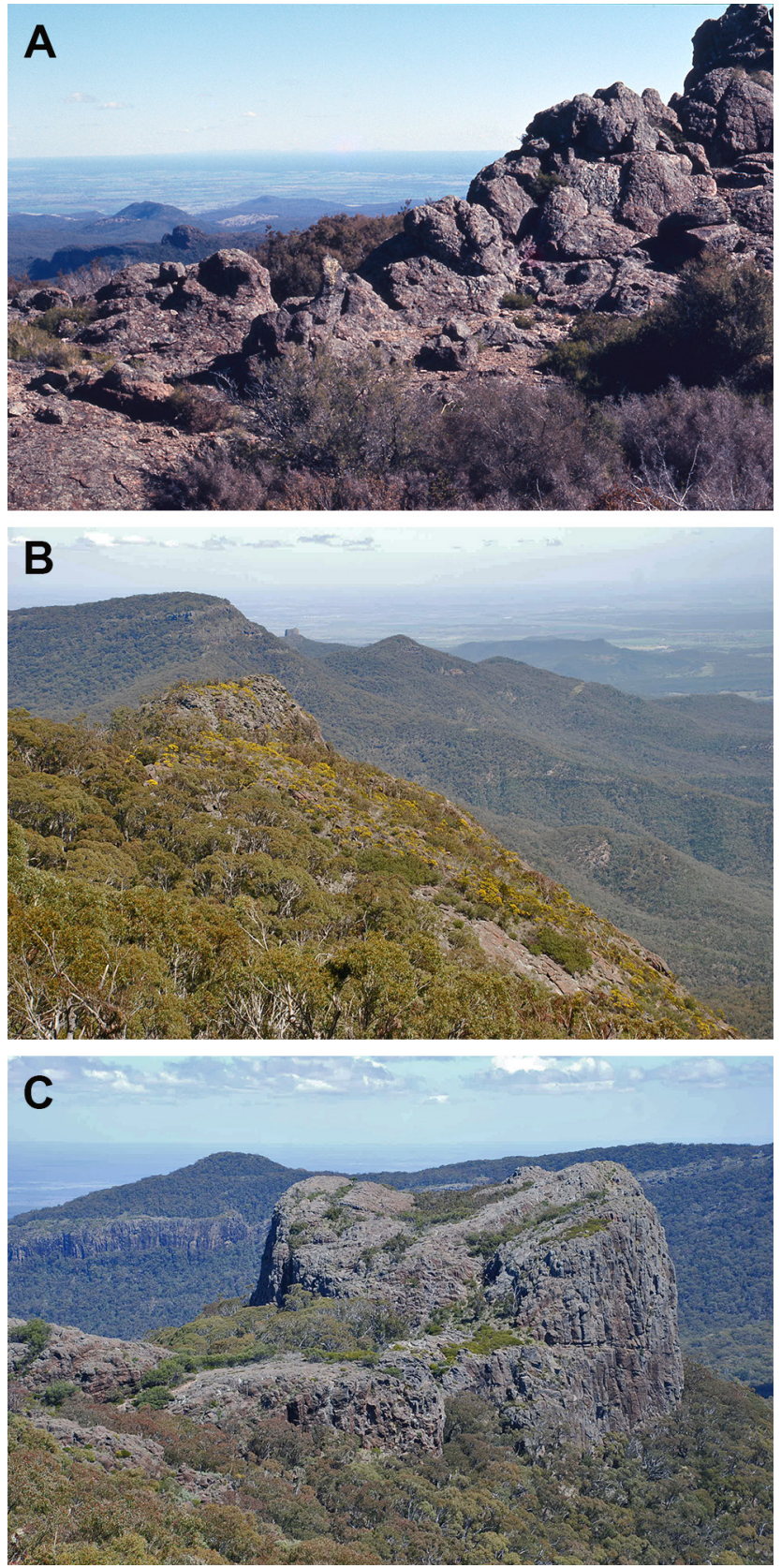

Figure 6. High elevation rock habitat of Egernia roomi, the summit region of the Nandewar Range $(A, B)$ and the base of the volcanic plug The Governor $(C)$.

a key factor in the presence of the Kaputar Rock Skink, the potential extent of occurrence of the species (EOO) is small $\left(241 \mathrm{~km}^{2}\right)$, even when based conservatively on an estimate of area above $1000 \mathrm{~m}$ in elevation, and the specific area it occupies (AOO) even lower $\left(134 \mathrm{~km}^{2}\right)$.

These observations should be regarded as indicative, given areas of rock habitat lower in elevation have yet to be systematically investigated. However, should future field studies further support the Kaputar Rock Skink as being confined to highly specific high elevation rock microhabitat, the species will have one of the narrowest environmental niches of any reptile species in New South Wales, and one that may become progressively narrower with rising temperature regimes. 
Evolutionary History of the Kaputar Rock Skink: The occurrence of species restricted to the higher elevation habitat of isolated peaks and plateaus on mountain chains has been well documented worldwide (see Haines et al., 2017), with the term 'sky islands' applied to such scenarios. Niche conservatism in species (Wiens, 2004) has been promoted as the primary driver for historical isolation to mountain tops, whereby taxa that are cool-adapted retreat upward in elevation with the onset of less favourable (warmer) climatic conditions, and theoretically downward under favourable conditions. The size and connectivity of many 'sky island' populations are thought to have fluctuated in response to Pliocene-Pleistocene glacial cycles.

In Australia contraction of montane habitat associated with Pliocene-Pleistocene interglacial cycles has been proposed to explain genetic diversification within cooladapted reptile species in the Australian Alps region of the Great Dividing Range (Haines et al., 2017), with expansion in range associated with periods of cooler conditions during glacial periods. In north-east Australia genetic diversification in moisture-dependent reptile taxa in the humid forests has been attributed to the contraction of forest habitat during periods of aridity associated with Pleistocene glacial cycles, with expansion in range during warmer and moister conditions of interglacial periods, and similar but older events of late-Miocene or early-Pliocene age have been proposed to explain the evolution of deeply divergent taxa restricted to the summit areas of mountain tops c. $1000 \mathrm{~m}$ in elevation in the Wet Tropics region of northeast Queensland (Schneider et al., 1998; Schneider \& Moritz, 1999; Moritz et al., 2000; Moritz et al., 2012). Either scenario result in the retreat upward in elevation of niche-conservative taxa unable to adapt to the changed conditions at lower elevations, and their isolation in montane refugia.

The study by Colgan et al. (2009) of phylogeographic patterns of the montane rock-dependent gecko species Oedura aff. lesueurii on the northern tableland region utilizing the $C y t b$ gene gave an average nucleotide difference of $8.8 \%$ between basal clades, with an estimated time of divergence of c. 3.5 million years ago, towards the early Pleistocene or before. The level of genetic differentiation between the Kaputar Rock Skink and east Australian striolata-group species is significantly greater (see Table 1), indicating isolation of the Kaputar Rock Skink to the Nandewar Ranges to be an historically older event than the Pleistocene glacial cycles.

The Kaputar Rock Skink now appears to be restricted to high elevation habitat on the Nandewar Range and to be a 'cool-adapted' species. Here we consider the possible evolutionary scenarios that may account for its present day distribution on the montane summits of the Nandewar Range, and other potential contributing factors that may also be involved. Little inference for this being a consequence of a 'montane' ancestry are apparent in the scheme of relationships derived from the genetic study, and the species' apparent reliance on montane habitat of the summit region of the Nandewar Range appear to be independently derived. The question remains as to what factors may have driven both the degree of habitat specificity and geographic isolation.

The summit area of the Nandewar Range has a group of several lizard species (P. pagenstecheri, Acritoscincus platynotum, Hemiergis talbingoensis) and one snake (Drysdalia coronoides) whose distributions otherwise are largely confined to higher elevation habitat of the Great Dividing Range, and could be regarded as 'cool-adapted' montane species. The presence of disjunct populations on the Nandewar Range indicates that habitat and climatic conditions suitable for 'cool-adapted' species existed at lower elevation in intervening areas historically.

To assess the extent and recency of historical connectivity of habitat suitable for 'cool-adapted' species between the Nandewar Range and adjacent northern tablelands we investigated the level of genetic divergence between the Nandewar population of the montane specialist skink $P$. pagenstecheri and other high elevation populations of that species. The level of genetic differentiation between the Coolah Tops, Nandewar Range and Riamukka populations was low, indicating historically recent gene flow between these populations. By implication, habitat with a thermal regime suitable for 'cool-adapted' lizard species existed in intervening areas in recent historical times, and its availability would not appear to have been a factor then in maintaining isolation of the Kaputar Rock to the Nandewar Range.

We also considered discontinuity of rocky habitat as a contributing factor to the historical isolation of the Kaputar Rock Skink by investigating the extent of genetic differentiation between several populations of the rock dependant gecko $U$. sphyrurus. Although limited to a few samples, the level of genetic differentiation detected between the Nandewar Range and adjacent western slopes near Copeton and the New England tablelands at Moonbi was low to moderate, but consistent with these being a part of a widespread population with some degree of substructure and no significant barriers to dispersal. From this we infer continuity of structurally suitable rock habitat in the area between the Nandewar Range and Great Dividing Range was likely to be present in historically recent times.

The independent studies undertaken on $P$. pagenstecheri and $U$. sphyrurus indicate neither an absence of thermally suitable montane habitat or lack of structurally suitable rock habitat to be a contributing factor in maintaining isolation of the Kaputar Rock Skink to the Nandewar Range in historically recent times. Rather, it would appear factors responsible for the species current isolation and reliance on high elevation habitat stem from deep in its history, and its biology now compatible only with the environmental niche offered by rock outcrops at high elevation. The term 'lithorefugia' was recently proposed by Couper \& Hoskin (2008) in describing the historical role of rock habitat as refugia in the evolution of a broad range of reptile species on the coastal ranges of central-east and northern Queensland. Here, the role of rock habitat as refugia for fauna is likely closely linked with its ability to also provide a refuge for the persistence of once more-widespread vegetation types, such as dry rain forest, under periods of historical aridity. This combination of attributes is considered the likely speciation mechanism behind the evolution of a number leaf-tailed geckos in the genus Phyllurus in mid-eastern Queensland (Stuart-Fox et al., 2001; Couper \& Hoskin, 2008).

The significance of rocky environments - lithorefugiain the western division of New South Wales as historical refuges for reptiles is now becoming apparent. This is not so much in the context of strongholds for arid zone species from which pulses of expansion and contraction in range emanate, but rather as retreat sites for mesic species once 
more widespread in distribution. Several species of lizards with primarily eastern distributions have highly disjunct outlying populations in the west of the state. The most extreme is the population of White's Skink Liopholis whitii from the Bynguano Range of Mutawintji National Park, $110 \mathrm{~km}$ to the north and east of Broken Hill (Swan \& Foster, 2005). Liopholis whitii has a core distribution along the Great Dividing Range, but extends also onto the western slopes to the Warrumbungle Ranges, approximately $650 \mathrm{~km}$ east of the population at Mutawintji. The extent of differentiation between the Mutawintji population of White's Skink and populations to the east was 3.2-4.3\% (16S and ND4 mitochondrial genes combined - Chapple \& Keogh, 2004), a level of divergence regarded as consistent with a split of Pliocene-early Pleistocene ancestry. The other example is a disjunct population of the Eastern Ranges Rock Skink Liopholis modesta on the Merrimerriwa Ranges of Yathong National Park in the central-west of the state. This species otherwise has a distribution restricted to the ranges of the northern tablelands and adjacent western slopes, but with populations extending onto the edge of the western plains near Moree and Walgett, $380 \mathrm{~km}$ northeast of the Yathong population. The highly disjunct populations of $L$. whitii and $L$. modesta now restricted to rocky ranges in the western division are considered to represent remnant populations from when these primarily 'mesic' species (Chapple \& Keogh, 2004) were once more widespread under different and more favourable climatic conditions, but have undergone severe recent historical contractions in range. It is likely the apparently long-term isolation of the Kaputar Rock Skink to the summit region of the Nandewar Range represents a similar scenario, but deeper in time.

A final possible contributing factor in the apparent restriction of the Kaputar Rock Skink to higher elevations on the Nandewar Range could be that of inter-specific competition with populations of E. striolata that are likely to occupy the adjacent lowlands. Cogger (1960) reported the east Australian striolata-group species E. striolata and E. saxatilis saxatilis as occurring in local sympatry in the Warrumbungle Ranges, but with mutually exclusive habitat preferences. He found E. saxatilis saxatilis to be confined to rock outcrops and screes on the upper parts of bluffs and spires whereas E. striolata occupied the surrounding woodland habitat and was strictly arboreal in habits. Egernia striolata may have played a similar role in maintaining isolation of the Kaputar Rock Skink by preventing its expansion downward to lower elevations during periods of more favourable climatic conditions historically, and even now. Egernia striolata is known from several nearby sites on the adjoining on the adjacent plains, but its occurrence on the lower slopes of the Nandewar Ranges and environs has yet to be established. It is also worth noting here that E. striolata has been recorded from c. $1000 \mathrm{~m}$ elevation on Coolah Tops, indicating that altitude alone, to this level, is not a barrier to dispersal upward in elevation for the species.

Implications for conservation of the Kaputar Rock Skink: The evidence available so far suggests the current narrow niche preference of the Kaputar Rock Skink is likely a product of its evolutionary history. Its apparent absence from rock or woodland microhabitat at lower elevations likely reflects the thermal unsuitability of microhabitats for the species lower on the ranges, and it requires rock outcrops at high elevation to provide suitable sheltering and foraging sites within an optimal climatic regime. However, the suitability of high elevation rock outcrops for the Kaputar Rock Skink may also extend to the capability of the rock habitat occupied in buffering against extremes of (low) temperature and dryness. In this respect not all rock habitat may be suitable for the species. Attributes such as the aspect, exposure with respect to the structure of surrounding vegetation and orientation towards the sun, extent of exposed rock, and availability and structure of retreat sites are all likely to determine site suitability. Although rock habitat is in itself robust to the impact of events such as wildfire and or seasonal extremes of heat and dryness (such as experienced in recent el niño cycles), these events are likely to affect food availability (both prey items and vegetative matter), and activity regimes (basking and foraging). Taking these factors into account the Kaputar Rock Skink could have an even more restricted area of occurrence, one which could be highly vulnerable to perturbation of its surrounding environment.

Haines et al. (2017) provided a comprehensive overview of the impact of climate change on 'sky island' species, focussing on the implications for cool-adapted reptile species. These impacts included a reduction in daily activity periods,
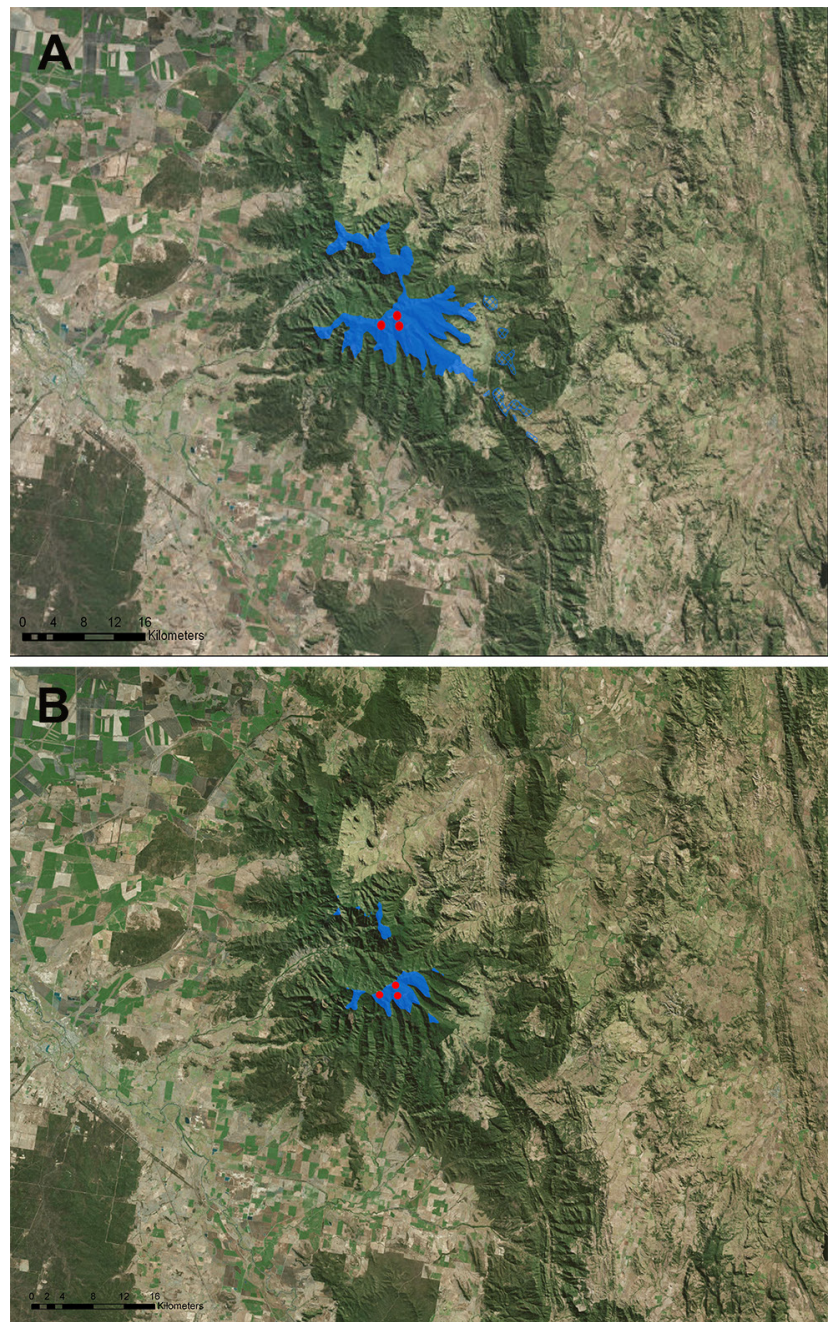

Figure 7. The projected extent of occurrence of the Kaputar Rock Skink Egernia roomi on the summit region of the Nandewar Range (area in blue) above $1000 \mathrm{~m}$ in elevation $(A)$ and above $1200 \mathrm{~m}$, with the 3 sites (red circles) from which the species has been recorded. 
physiological stress, increased competition from other species in the face of a shrinking ecosystem, and greater disconnectivity between isolate populations. Based on the information currently available, a similar suite of impacts are likely to affect the Kaputar Rock Skink with climatic warming.

Current New South Wales and federal threatened species legislation (Environment Protection and Biodiversity Conservation Act 1999; Biodiversity Conservation Act 2016) uses the tenets of IUCN Red List criteria in assessing levels of threat to species. The Kaputar Rock Skink has a predicted area of occupancy (AOO) considerably less than $500 \mathrm{~km}^{2}$ and only occurs at one location (the Nandewar Range), and on this basis meets the geographic range criteria for consideration as highly threatened. However, the status of the species with regard to observed, estimated, inferred or projected threats that could affect the quality of its very specific preferred habitat requires further investigation (Fig. 7).

Among the potential threats that could complicate the long-term integrity of the preferred habitat of the Kaputar Rock Skink are the impact of invasive species, fire, human visitation and climate change. Goats can alter the ecology of rocky habitat and the areas immediately adjacent, and their control has been identified as a management priority for KNP (Hunter, 2015) and is part of the park management plan (DEC, 2006). The impact of an intense fire event on resident populations could lie more with the after-effects associated with loss of surrounding vegetation, including reduced invertebrate prey for food and altered microclimate. Human-mediated disturbance of habitat is an issue at sites close to the edge of cliff lines that are readily accessible by walking tracks. Trampling of low vegetation was evident at many sites, and disturbed rocks were observed at Mt Dowe, The Governor and elsewhere in KNP during our 2015 field studies, the latter presumably by persons wanting to locate reptiles. Habitat disturbance of this kind was observed over an extensive area of granite outcrops in the vicinity of Kanangra Walls on the central tablelands (RAS, pers. obs.), resulting in a reduction of sheltering sites for populations of E. saxatilis intermedia, the Black Rock Skink. Altering the placement of rocks likely alters the microenvironment beneath the rock, rendering it unsuitable for reptiles that utilize rock crevices as sheltering sites.

However, the most significant threat to the extent of suitable habitat available to the Kaputar Rock Skink comes from an inferred narrowing of the available altitudinal niche occupied by the species from climate change induced warming. Distinct sub-alpine vegetation communities occur on the Nandewar Range at areas above the snowline at $1200 \mathrm{~m}$ in elevation. The Kaputar Rock Skink has so far only been recorded from between 1360 and $1480 \mathrm{~m}$ in elevation. It is possible its lower elevational range is also limited by similar environmental parameters that restrict the elevational limits of sub-alpine vegetation communities on the Nandewar Range. If this is the case, an estimate of area of Area of Occupancy (AOO) of $134 \mathrm{~km}^{2}$ and Extent of Occurrence (EOO) of $241 \mathrm{~km}^{2}$ being based on most high elevation rock habitat being above 1000 $m$ in elevation, could represent a substantial overestimate of potential area occupied by the species. A reduction in range of elevation of only $200 \mathrm{~m}$ to areas above the snowline at $>1200$ $\mathrm{m}$ (still $150 \mathrm{~m}$ below the lowest known record) would result in a significant reduction of predicted area AOO to $30 \mathrm{~km}^{2}$ and $\mathrm{EOO}$ to $122 \mathrm{~km}^{2}$.
AcKnowledgments. We thank Mrs Mary Holt and the late Dr John Holt for funding and James Faris (OEH, Narrabri) for advice and support. Timothy Cutajar produced the map of striolata-group species presented in Fig. 3 and predicted areas of occurrence in Fig. 7, and Corin Sadlier for assistance with Fig. 4.

\section{References}

Australian Society of Herpetologists. 1987. Case 2531. Three works by Richard W. Wells and Ross C. Wellington: proposed suppression for nomenclatural purposes. Bulletin of Zoological Nomenclature 44(2): 116-121. https://doi.org/10.5962/bhl.part.287.

Brovey Mapping Services. Brovey Mapping Services. Nandewar Volcano Geological Drive. [Accessed 6 August 2019] http://brovey.yolasite.com/resources/Nandewar_geo_tour.pdf

Cartoscope. Geological Sites of New South Wales-Mt Kaputar National Park. [Accessed 4 February 2019] http://www.geomaps.com.au/scripts/mountkaputar.php

Chapple, D. G., and S. J. Keogh. 2004. Parallel adaptive radiations in arid and temperate Australia: molecular phylogeography and systematics of the Egernia whitii (Lacertilia: Scincidae) species group. Biological Journal of the Linnean Society 83: 157-173. https://doi.org/10.1111/j.1095-8312.2004.00378.x

Cogger, H. G. 1960. The ecology, morphology, distribution and speciation of a new species and subspecies of the genus Egernia (Lacertilia: Scincidae). Records of the Australian Museum 25(5): 95-105.

https://doi.org/10.3853/j.0067-1975.25.1960.657

Cogger, H. G. 2014. Reptiles and Amphibians of Australia, 7th edition. Victoria: CSIRO Publishing.

Colgan, D. J., D. O’Meally, and R. A. Sadlier. 2009. Phylogeographic patterns in reptiles on the New England Tablelands at the southwestern boundary of the McPherson Macleay Overlap. Australian Journal of Zoology 57: 317-328. https://doi.org/10.1071/Z008088

Couper, P. J., and C. J. Hoskin. 2008. Litho-refugia: the importance of rock landscapes for the long-term persistence of Australian rainforest fauna. Australian Zoologist 34(4): 554-560. https://doi.org/10.7882/AZ.2008.032

DEC. 2006. Mount Kaputar National Park Plan of Management. NSW National Parks and Wildlife Service part of Department of Environment and Conservation (NSW), 42 pp.

Gardner, M. G., A. F. Hugall, S. C. Donnellan, M. N. Hutchinson, and R. Foster. 2008. Molecular systematics of social skinks: phylogeny and taxonomy of the Egernia group (Reptilia: Scincidae). Zoological Journal of the Linnean Society 154: 781-794. https://doi.org/10.1111/j.1096-3642.2008.00422.x

Greer, A. E. 1979. A phylogenetic subdivision of Australian skinks. Records of the Australian Museum 32: 339-371. https://doi.org/10.3853/j.0067-1975.32.1979.459

Haines, M. L., D. Stuart-Fox, J. Sumner, N. Clemann, D. G. Chapple, and J. Melville. 2017. A complex history of introgression and vicariance in a threatened montane skink (Pseudemoia cryodroma) across an Australian sky island system. Conservation Genetics 18(4): 939-950. https://doi.org/10.1007/s10592-017-0945-7

Hijmans, R. J., S. E. Cameron, J. L. Parra, P. G. Jones, and A. Jarvis. 2005. Very high resolution interpolated climate surfaces for global land areas. International Journal of Climatology 25(15): 1965-1978. https://doi.org/10.1002/joc.1276

Honda, M., H. Ota, M. Kobayashi, J. Nabhitabhata, H.-S. Yong, and T. Hikida. 2000. Phylogenetic relationships, character evolution, and biogeography of the subfamily Lygosominae (Reptilia: Scincidae) inferred from mitochondrial DNA sequences. Molecular Phylogenetics and Evolution 15: 452-461. https://doi.org/10.1006/mpev.1999.0767 
Hunter, J. 2015. Vegetation and Flora of Mt Kaputar National Park. Researchgate https://doi.org/10.13140/RG.2.1.3135.3444

ICZN. 1991. Decision of the Commission. Three works by Richard W. Wells and Ross C. Wellington: proposed suppression for nomenclatural purposes. Bulletin of Zoological Nomenclature 48(4): 337-338.

IUCN. 2012. IUCN Red List Categories and Criteria: Version 3.1. Second edition. Gland, Switzerland and Cambridge, UK: IUCN: 32 pp.

Kocher, T. D., W. K. Thomas, A. Meyer, S. V. Edwards, S. Paabo, F. X. Villablanca, and A. C. Wilson. 1989. Dynamics of mitochondrial DNA evolution in animals: amplification and sequencing with conserved primers. Proceedings of the National Academy of Sciences 86: 6196-6200. https://doi.org/10.1073/pnas.86.16.6196

Moritz, C. 1994. Defining 'Evolutionarily Significant Units' for conservation. TREE 9(10): 373-375. https://doi.org/10.1016/0169-5347(94)90057-4

Moritz, C., G. Langham, M. Kearney, A. Krockenberger, J. VanDerWal, and S. Williams. 2012. Integrating phylogeography and physiology reveals divergence of thermal traits between central and peripheral lineages of tropical rainforest lizards. Philosophical Transactions of the Royal Society B 367: 1680-1687. https://doi.org/10.1098/rstb.2012.0018

Moritz, C., J. I. Patton, C. J. Schneider, and T. B. Smith. 2000. Diversification of rainforest faunas: an integrated molecular approach. Annual Review of Ecology and Systematics 31: 533-563. https://doi.org/10.1146/annurev.ecolsys.31.1.533

Nei, M., and S. Kumar. 2000. Molecular Evolution and Phylogenetics. New York: Oxford University Press.

Rambaut, A., M. A. Suchard, D. Xie, and A. J. Drummond. 2016. Tracer v. 1.6. Institute of Evolutionary Biology, University of Edinburgh.

Ronquist, F., M. Teslenko, P. Van Der Mark, D. L. Ayres, A. Darling, S. Höhna, B. Larget, L. Liu, M. A. Suchard, and J. P. Huelsenbeck. 2012. MrBayes 3.2: efficient Bayesian phylogenetic inference and model choice across a large model space. Systematic Biology 61(3): 539-542. https://doi.org/10.1093/sysbio/sys029

Sadlier, R. A., D. J. Colgan, and G. M. Shea. 1993. Taxonomy and distribution of the Australian scincid lizard Saproscincus challengeri and related species in southeastern Australia. Memoirs of the Queensland Museum 34(1): 139-158.

Sadlier, R. A., P. J. Couper, D. J. Colgan, E. Vanderduys, and E. Rickard. 2005. A new species of scincid lizard, Saproscincus eungellensis, from mid-eastern Queensland. Memoirs of the Queensland Museum 51(2): 559-571.

Schneider, C. J., M. Cunningham, and C. Moritz. 1998. Comparative phylogeography and the history of endemic vertebrates in the Wet Tropics rainforest of Australia. Molecular Ecology 7: 487-498.

https://doi.org/10.1046/j.1365-294x.1998.00334.x
Schneider, C. J., and C. Moritz. 1999. Rainforest refugia and evolution in Australia's Wet Tropics. Proceedings of the Royal Society of London B 266: 191-196.

https://doi.org/10.1098/rspb.1999.0621

Shea, G. M. 1987. Comment on the proposed suppression for nomenclatural purposes of three works by Richard W. Wells and Ross C. Wellington. Bulletin of Zoological Nomenclature 44(4): 257-261. https://doi.org/10.5962/bhl.part.349

Shea, G. M., and R. A. Sadlier. 1999. A catalogue of the nonfossil amphibian and reptile type specimens in the collection of the Australian Museum. Technical Reports of the Australian Museum 15: 1-91. https://doi.org/10.3853/j.1031-8062.15.1999.1290

Stuart-Fox, D. M., C. J. Schneider, C. Moritz, and P. J. Couper. 2001. Comparative phylogeography of three rainforest restricted lizards from mid-east Queensland. Australian Journal of Zoology 49: 119-127. https://doi.org/10.1071/Z000092

Swan, G., and R. Foster. 2005. The reptiles and amphibians of Mutawintji National Park, western New South Wales. Australian Zoologist 33(1): 39-48. https://doi.org/10.7882/AZ.2005.003

Swan, G., R. Sadlier, and G. Shea. 2017. A Field Guide to Reptiles of New South Wales, 3rd edition. Sydney: Reed New Holland Publishers Pty Ltd., 328 pp.

Swan, G., G. Shea, and R. Sadlier. 2014. A Field Guide to Reptiles of New South Wales, 2nd edition. Sydney: Reed New Holland Publishers Pty Ltd., 302 pp.

Tamura, K., G. Stecher, D. Peterson, A. Filipski, and S. Kumar. 2013. MEGA6: Molecular Evolutionary Genetics Analysis version 6.0. Molecular Biology and Evolution 30(12): 2725-2729. https://doi.org/10.1093/molbev/mst197

Wells, R., and C. R. Wellington. 1984. A synopsis of the class Reptilia in Australia. Australian Journal of Herpetology 1: 73-129.

Wells, R., and C. R. Wellington. 1985. A classification of the Amphibia and Reptilia of Australia. Australian Journal of Herpetology, Supplementary Series no. 1, 1-61.

Wiens, J. J. 2004. Speciation and ecology revisited: phylogenetic niche conservatism and the origin of species. Evolution 58(1): 193-197.

https://doi.org/10.1111/j.0014-3820.2004.tb01586.x

Wilson, S. K. 2015. A Field Guide to Reptiles of Queensland, 2nd edition. Sydney: Reed New Holland Publishers Pty Ltd., 304 pp.

Wilson, S., and G. Swan. 2017. A Complete Guide to Reptiles of Australia, 5th edition. Sydney: Reed New Holland Publishers Pty Ltd., 647 pp. 


\section{Appendix 1}

Specimens of east Australian members of the Egernia striolata-group and the outgroup taxa used in the genetics study. Written locations are generalized for brevity, full location data resides in the Australian Museum Herpetology collection registers. Australian Museum, Sydney (AMS) register numbers are prefixed $R$.

\begin{tabular}{|c|c|c|c|}
\hline AMS & \multicolumn{2}{|c|}{ GenBank No. species } & location \\
\hline R.152130 & MN270184 & E. roomi & Mt Kaputar NP, Mt Kaputar summit (30¹6'23"S 15009'51"E) \\
\hline R.152131 & MN270185 & E. roomi & Mt Kaputar NP, Mt Kaputar summit ( $\left.30^{\circ} 16^{\prime} 23^{\prime \prime S} 150^{\circ} 09^{\prime} 51^{\prime \prime E}\right)$ \\
\hline R.152132 & MN270186 & E. roomi & Mt Kaputar NP, Mt Kaputar summit ( $30^{\circ} 16^{\prime} 23^{\prime \prime S} 150^{\circ} 09^{\prime} 51^{\prime E}$ ) \\
\hline R.184673 & MN270187 & E. roomi & Mt Kaputar NP, Mt Dowe (30¹7'01"S 150¹0'01"E) \\
\hline R.184672 & MN270188 & E. roomi & Mt Kaputar NP, Governor Track $\left(30^{\circ} 15^{\prime} 58^{\prime \prime S} 150^{\circ} 08^{\prime} 44^{\prime E}\right)$ \\
\hline R.149294 & MN270189 & E. mcpheei & Gibraltar Range NP $\left(29^{\circ} 31^{\prime} 03^{\prime \prime S} 152^{\circ} 21^{\prime} 33^{\prime \prime E}\right)$ \\
\hline R.150174 & MN270190 & E. mcpheei & North Haven $\left(31^{\circ} 38^{\prime} \mathrm{S} 152^{\circ} 49^{\prime} \mathrm{E}\right)$ \\
\hline R.153859 & MN270191 & E. mcpheei & Acacia Plateau (28¹7'41"S 152²6'35"E) \\
\hline R.153864 & MN270192 & E. mcpheei & Undercliffe Falls (28³8'49"S 15209'59"E) \\
\hline R.157153 & MN270193 & E. mcpheei & Forestlands State Forest, Bald Rock $\left(29^{\circ} 13^{\prime} 41^{\prime \prime S} 152^{\circ} 07^{\prime} 25^{\prime \prime E}\right)$ \\
\hline R.174861 & MN270194 & E. mcpheei & Comboyne $\left(31^{\circ} 34^{\prime} 12^{\prime \prime S} 152^{\circ} 27^{\prime} 25^{\prime \prime} \mathrm{E}\right)$ \\
\hline R.174862 & MN270195 & E. mcpheei & Comboyne $\left(31^{\circ} 34^{\prime} 12^{\prime \prime S} 152^{\circ} 27^{\prime} 25^{\prime \prime E}\right)$ \\
\hline R.174863 & MN270196 & E. mcpheei & Comboyne NR, Mt Bulli (313'ㅇ $\left.152^{\circ} 28^{\prime} \mathrm{E}\right)$ \\
\hline R.181708 & MN270197 & E. mcpheei & 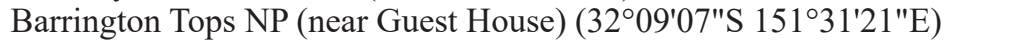 \\
\hline R.152150 & MN270198 & E. s. saxatilis & Warrumbungle NP, Timor Rock $\left(31^{\circ} 15^{\prime} 59^{\prime \prime S} 149^{\circ} 09^{\prime} 31^{\prime \prime E}\right)$ \\
\hline R. 152151 & MN270199 & E. s. saxatilis & Warrumbungle NP, Timor Rock (31ำ15'59"S $\left.149^{\circ} 09^{\prime} 31^{\prime \prime E}\right)$ \\
\hline R.156064 & MN270200 & E. s. saxatilis & Warrumbungle NP, Timor Rock ( $\left.31^{\circ} 15^{\prime} 59^{\prime \prime S} 149^{\circ} 09^{\prime} 31^{\prime \prime E}\right)$ \\
\hline R.177124 & MN270201 & E. s. intermedia & Kosciuszko NP, near Clover Flat camping area $\left(36^{\circ} 05^{\prime} 11^{\prime \prime S} 148^{\circ} 11^{\prime} 03^{\prime \prime E}\right)$ \\
\hline R.177125 & MN270202 & E. s. intermedia & Kosciuszko NP, near Clover Flat camping area $\left(36^{\circ} 05^{\prime} 11^{\prime \prime S} 148^{\circ} 11^{\prime} 03^{\prime \prime E}\right)$ \\
\hline R.177126 & MN270203 & E. s. intermedia & Kosciuszko NP, near Clover Flat camping area $\left(36^{\circ} 05^{\prime} 11^{\prime \prime S ~} 148^{\circ} 11^{\prime} 03^{\prime \prime E}\right)$ \\
\hline R.181663 & MN270204 & E. s. intermedia & Kanangra-Boyd NP $\left(33^{\circ} 58^{\prime} \mathrm{S} 150^{\circ} 03^{\prime} \mathrm{E}\right)$ \\
\hline R.181683 & MN270205 & E. striolata & Amiens $\left(28^{\circ} 35^{\prime} 41^{\prime \prime S ~} 151^{\circ} 48^{\prime} 44^{\prime \prime E}\right)$ \\
\hline R.157169 & MN270206 & E. striolata & Tenterfield (2906'56"S 15153'13"E) \\
\hline R.149297 & MN270207 & E. striolata & 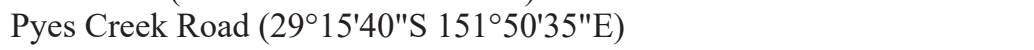 \\
\hline R.149298 & MN270208 & E. striolata & Pyes Creek Road (29¹5'40"S 15150'35"E) \\
\hline R.149299 & MN270209 & E. striolata & Pyes Creek Road (29¹5'40"S 15150'35"E) \\
\hline R. 159658 & MN270210 & E. striolata & Yarrowyck $\left(30^{\circ} 28^{\prime} 21^{\prime \prime S} 151^{\circ} 22^{\prime} 17^{\prime \prime E}\right)$ \\
\hline R.157013 & MN270211 & E. striolata & Yarrowyck $\left(30^{\circ} 28^{\prime} 21^{\prime \prime S} 151^{\circ} 22^{\prime} 17^{\prime \prime E}\right)$ \\
\hline R.159532 & MN270212 & E. striolata & Moonbi Ranges (3059'33"S 1510.5'00"E) \\
\hline R.156548 & MN270213 & E. striolata & Limbri (3100'53"S $\left.151^{\circ} 10^{\prime} 04^{\prime \prime E}\right)$ \\
\hline R.156549 & MN270214 & E. striolata & Limbri $\left(31^{\circ} 00^{\prime} 53 " \mathrm{~S} 151^{\circ} 10^{\prime} 04 " \mathrm{E}\right)$ \\
\hline R.153094 & MN270215 & E. striolata & 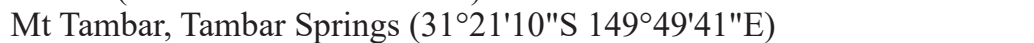 \\
\hline R.153095 & MN270216 & E. striolata & Mt Tambar, Tambar Springs (31²1'10"S 14949'41"E) \\
\hline R.185789 & MN270217 & E. striolata & Coolah Tops $\left(31^{\circ} 49^{\prime} 14^{\prime \prime S} 150^{\circ} 12^{\prime} 18^{\prime \prime E}\right)$ \\
\hline R.185790 & MN270218 & E. striolata & Coolah Tops (3149'14"S 150¹2'18"E) \\
\hline R.185791 & MN270219 & E. striolata & Coolah Tops (3149'17"S 150¹2'19"E) \\
\hline R.151554 & MN270220 & E. striolata & Gingham floodplain $\left(29^{\circ} 19^{\prime} 20^{\prime \prime S} 149^{\circ} 27^{\prime} 24^{\prime \prime E}\right)$ \\
\hline R. 152250 & MN270221 & E. striolata & Gingham floodplain $\left(29^{\circ} 15^{\prime} 49^{\prime \prime S} 149^{\circ} 18^{\prime} 00^{\prime \prime E}\right)$ \\
\hline R.153303 & MN270222 & E. striolata & Mungindi (28॰58'06"S 14903'20"E) \\
\hline R.164806 & MN270223 & E. striolata & Gundabooka NP, Mt Gundabooka (30³5'27"S 14541'09"E) \\
\hline R.162951 & MN270224 & E. striolata & Griffith $\left(34^{\circ} 06^{\prime} 18^{\prime \prime S} 146^{\circ} 35^{\prime} 48^{\prime \prime E}\right)$ \\
\hline R.142772 & MN270225 & E. striolata & Strathvale, $5 \mathrm{~km} \mathrm{~N}$ Strathvale (340 $\left.07^{\prime} \mathrm{S} 148^{\circ} 49^{\prime} \mathrm{E}\right)$ \\
\hline R. 142773 & MN270226 & E. striolata & Strathvale, $5 \mathrm{~km} \mathrm{~N}$ Strathvale $\left(34^{\circ} 07^{\prime} \mathrm{S} 148^{\circ} 49^{\prime} \mathrm{E}\right)$ \\
\hline R.141105 & MN270227 & E. striolata & Buddigower NR $\left(34^{\circ} 03^{\prime} \mathrm{S} 147^{\circ} 01^{\prime} \mathrm{E}\right)$ \\
\hline R.156524 & MN270228 & E. striolata & Yathong (3241'48"S 145³2'33”E) \\
\hline R.153322 & MN270229 & E. striolata & Yathong $\left(32^{\circ} 37^{\prime} 56^{\prime \prime S} 145^{\circ} 35^{\prime} 10^{\prime \prime E}\right)$ \\
\hline R.145579 & MN270230 & E. striolata & Mootwingee $\left(31^{\circ} 17^{\prime} \mathrm{S} 142^{\circ} 18^{\prime} \mathrm{E}\right)$ \\
\hline R.177201 & MN270231 & E. formosa & Coolgardie $\left(31^{\circ} 00^{\prime} 46^{\prime \prime S ~} 121^{\circ} 16^{\prime} 56^{\prime \prime E}\right)$ \\
\hline R.177202 & MN270232 & E. formosa & Coolgardie ( $\left.31^{\circ} 00^{\prime} 46^{\prime \prime S} 121^{\circ} 16^{\prime} 56^{\prime \prime E}\right)$ \\
\hline R.167612 & MN270233 & E. cunninghami & Atholwood $\left(28^{\circ} 59^{\prime} 32^{\prime \prime} \mathrm{S} 151^{\circ} 08^{\prime} 42^{\prime \prime} \mathrm{E}\right)$ \\
\hline R. 165740 & MN270234 & Tiliqua scincoides & Bourke-Wanaaring Rd, $108 \mathrm{~km}$ W Bourke $\left(29^{\circ} 58^{\prime} \mathrm{S} 144^{\circ} 58^{\prime} \mathrm{E}\right)$ \\
\hline R.156520 & MN270235 & Liopholis inornata & Yathong NR (32³4'20"S 145²2'56"E) \\
\hline
\end{tabular}




\section{Appendix 2}

Specimens of Pseudemoia pagenstecheri and Uvidicolus sphyrurus used in supplementary genetics study, all in Australian Museum, Sydney (AMS); register numbers are prefixed $R$.

\begin{tabular}{|c|c|c|c|}
\hline AMS & GenBank no. & species & location \\
\hline R.153074 & MN270236 & P. pagenstecheri & Mt Kaputar NP, Dawsons Spring (30¹6'51"S 15009'50"E) \\
\hline R.152142 & MN270237 & P. pagenstecheri & Mt Kaputar NP, Mt Kaputar summit (30¹6'23"S 15009'51"E) \\
\hline R.152167 & MN270238 & P. pagenstecheri & 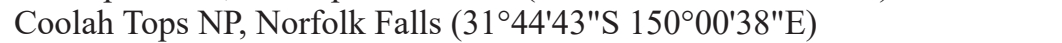 \\
\hline R.148168 & MN270239 & & r Area $\left(31^{\circ} 19^{\prime} 39^{\prime \prime S} 151^{\circ} 39^{\prime} 21^{\prime \prime E}\right)$ \\
\hline R. 148170 & MN270240 & P. $p$ & Riamukka State Forest (North Side), Grundy Fire Tower Area \\
\hline R.147100 & MN270241 & P. pagenstecheri & Stewarts Brook State Forest, Polblue Swamp (31ํ5' $\left.16^{\prime \prime S} 151^{\circ} 25^{\prime} 42^{\prime \prime E}\right)$ \\
\hline 101 & & P. $p a$ & 25'42"E) \\
\hline R.177158 & MN270243 & P. pag & 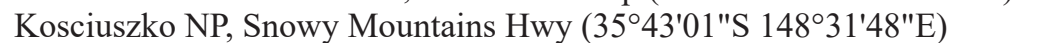 \\
\hline R.177160 & MN270244 & P. pagenstecheri & 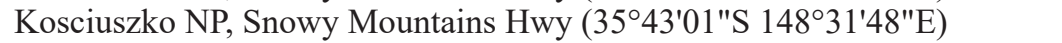 \\
\hline R.148523 & MN270245 & P. pagenstecheri & Kosciuszko NP, Charlottes Pass \\
\hline R.140837 & MN270246 & U. sphyrurus & Moonbi Lookout (3059'S 15105'E) \\
\hline R.140838 & MN270247 & U. sphyrurus & Gum Flat, between old Howell Mine and Copeton Dam $\left(29^{\circ} 56^{\prime} \mathrm{S} 151^{\circ} 01^{\prime} \mathrm{E}\right)$ \\
\hline R.152351 & MN270248 & U. sphyrurus & Kaputar National Park, Mt. Yulladunida $\left(30^{\circ} 17^{\prime} 18^{\prime \prime S} 150^{\circ} 04^{\prime} 55^{\prime \prime E}\right)$ \\
\hline
\end{tabular}

